\title{
Peak torque and knee kinematics during gait after eccentric isokinetic training of quadriceps in healthy subjects
}

\author{
O pico de torque e a cinemática do joelho durante a marcha após treino \\ isocinético excêntrico do quadríceps em sujeitos saudáveis
}

Poletto PR', Santos HH', Salvini TF', Coury HJCG', Hansson GA²

\begin{abstract}
Objective: To evaluate the effects of eccentric isokinetic training on knee range of motion (ROM) of healthy subjects. Methods: The knee extensor and flexor isokinetic peak torques and ROM of flexion/extension and varus/valgus knee movements during gait of 18 healthy men (21.7 \pm 2.2 years; $1.73 \pm 0.10 \mathrm{~m} ; 68.7 \pm 9.4 \mathrm{~kg}$; body mass index: $\left.22.6 \pm 2 \mathrm{~kg} / \mathrm{m}^{2}\right)$ were analyzed, before and after six weeks of bilateral eccentric isokinetic training of the knee extensors at $30 \%$ s. Results: The knee extensor torque increased in both limbs (right, from $229 \pm 54$ to $304 \pm 53 \mathrm{Nm} ; \mathrm{p}<0.01$; and left, from $228 \pm 59$ to $311 \pm 63 \mathrm{Nm} ; \mathrm{p}<0.01$ ), without any difference in torque gain between them. The knee flexor peak torque increased (from $114 \pm 30$ to $123 \pm 22 \mathrm{Nm} ; \mathrm{p}<0.05$ ), but the hamstrings/quadriceps $(H / Q)$ ratio decreased (from $0.5 \pm 0.08$ to $0.39 \pm 0.07 ; p<0.01$ ) after the training. There were no differences in the flexion/extension and varus/valgus movements after the training, except for a small change $\left(4^{\circ}\right)$ in valgus for the left knee. Conclusions: The eccentric isokinetic training of the knee extensors increased the extensor torque and decreased the $H / Q$ ratio, although the effect on the gait pattern seemed negligible in healthy subjects. Associated training for flexors, complementary to the extensor training, seems to be necessary for balance between knee agonists and antagonists.
\end{abstract}

Article registered in the Australian New Zealand Clinical Trials Registry (ANZCTR) under the number: 12607000590460.

Key words: electrogoniometer; gait; torque; knee; eccentric training.

\section{Resumo}

Objetivo: Avaliar os efeitos do treino isocinético excêntrico sobre a amplitude de movimento (ADM) do joelho em sujeitos saudáveis. Métodos: Foram analisados os picos de torque isocinético dos extensores e flexores do joelho e a ADM de flexo/extensão e valgo/

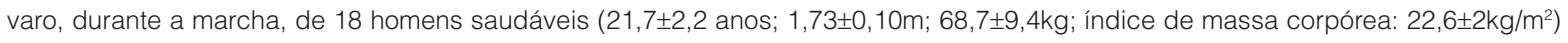
antes e após seis semanas de treino isocinético excêntrico bilateral dos extensores do joelho a $30 \%$ s. Resultados: $O$ torque extensor do joelho aumentou em ambos os membros, direito (de 229 \pm 54 para $304 \pm 53 \mathrm{Nm} ; \mathrm{p}<0,01$ ) e esquerdo (de $228 \pm 59$ para $311 \pm 63 \mathrm{Nm}$; $p<0,01$ ) sem diferença de ganho de torque entre eles. O pico de torque flexor aumentou (de $114 \pm 30$ para $123 \pm 22 \mathrm{Nm} ; \mathrm{p}<0,05$ ), mas a razão isquiotibiais/quadríceps $(I / Q)$ diminuiu (de $0,5 \pm 0,08$ para $0,39 \pm 0,07 ; p<0,01$ ) após o treino. Não houve diferença para os movimentos de flexo/extensão e valgo/varo após o treino, exceto uma pequena mudança $\left(4^{\circ}\right)$ no valgo para o joelho esquerdo. Conclusões: $O$ treino isocinético excêntrico dos extensores do joelho aumentou o torque extensor e diminuiu a razão $I / Q$, entretanto o efeito sobre o padrão da marcha parece desprezível em sujeitos saudáveis. Um treino associado dos flexores, complementar ao treino dos extensores parece ser necessário para o equilíbrio entre agonistas e antagonistas do joelho.

Artigo registrado na Australian New Zealand Clinical Trials Registry (ANZCTR) sob o número: 12607000590460.

Palavras-chave: eletrogoniômetro; marcha; torque; joelho; treino excêntrico.

Recebido: 08/11/077 - Revisado: 23/04/08 - Aceito: 10/06/08 


\section{Introduction $: \because$.}

Injuries and ligament reconstructions of the knee have been associated with changes in kinematic patterns during gait ${ }^{1-3}$. An altered gait, secondarily to ligament injury or reconstruction, may produce unfavorable loading of the cartilage of the knee joint ${ }^{4}$, and thus it may contribute to the development of arthritis 5 . Changes in gait pattern may occur as a consequence of joint tissue derangement, knee joint swelling, weakness of the quadriceps femoris muscle or muscle inhibition due to pain ${ }^{6}$. Atrophy of the extensor muscles is a common finding among patients undergoing anterior cruciate ligament (ACL) reconstruction ${ }^{7-9}$. Therefore, recovery of knee extensor strength is essential for functional rehabilitation. Previous reports have shown that the functional outcome is positively correlated with extensor strength, thus indicating that muscle strengthening is a precondition for functional recovery ${ }^{7,8}$.

It has been reported that training using eccentric contractions is more effective for muscle recovery because it promotes greater changes in neural activation and muscle hypertrophy ${ }^{9-12}$. Both force generation and stretching are major factors in activating protein synthesis, and the combination of these stimuli apparently has a pronounced additive effect ${ }^{13}$. Moreover, loaded eccentric exercise is a potent stimulus for hypertrophy ${ }^{14,15}$ and increases muscle strength ${ }^{16}$.

In a recent study ${ }^{17}$ in which we applied eccentric isokinetic training of the quadriceps muscles to subjects who had undergone ACL reconstruction, the knee extensor torque and flexion/ extension range of motion (ROM) during gait increased significantly after training. However, unexpectedly increased valgus, which was most pronounced during the swing phase, along with increased valgus/varus ROM. These kinematic changes, which may imply adverse effects on the knee, were also observed in the ACL reconstructed knees when compared with the healthy untrained subjects. In this respect, it would be also important to examine the effect of isokinetic eccentric training on knee ROM in control groups (subjects with healthy knees).

Thus, this study had the objective of evaluating the effects of eccentric isokinetic training on the strength of the extensor and flexor muscles of the knee, and the sagittal and coronal knee movements during gait, in healthy male subjects. In addition, the present stride-based method for characterizing gait was compared with the method used in our previous study ${ }^{17}$.

\section{Materials and methods $: \because$.}

\section{Subjects}

Initially, the sample was 25 subjects, but only 18 completed the study. These 18 healthy and active males (four with right dominance and 14 with left dominance) did not present any musculoskeletal injuries or symptoms or equilibrium disorders (age 21.7 \pm 2.2 years; height $1.73 \pm 0.10 \mathrm{~m}$; weight $68.7 \pm 9.4 \mathrm{~kg}$; body mass index: $22.6 \pm 2.0 \mathrm{~kg} / \mathrm{m}^{2}$ ). Their occupational and recreational activities did not change, and none of them was involved in any other training program to improve muscle strength, during the present study. This study was developed with approval from the Ethics Committee for Human Investigation of the Universidade Federal de Sao Carlos (UFSCar), number 144/2004 and all the subjects signed an informed consent statement.

\section{Eccentric training}

The training was performed twice a week for six consecutive weeks, totaling 12 sessions. The extensor muscles of both the right and left knees were trained during each session. To avoid any systematic differences, the left knee was trained first in one session and the right knee first in the subsequent session. This procedure was repeated for the rest of the training. Eighteen subjects completed the training program, which had been developed in the Muscle Plasticity Unit of the Neurosciences Laboratory of UFSCar ${ }^{18}$.

The subjects warmed up for five minutes on a cycle ergometer $(75 \mathrm{~W})$ and then the right and left quadriceps, hamstrings and calf muscles were stretched three times (30s of stretch with 30 s rest). Next, the subjects were seated on the isokinetic dynamometer (Biodex Multi-Joint System 3, Biodex Medical Inc. ${ }^{\circledR}$, Shirley, New York, USA) with the backrest reclined $5^{\circ}$ from vertical and straps fixing the trunk, waist and distal thigh. The lateral femoral epicondyle was used as the body landmark for matching the rotation axes of the knee joint and the lever arm of the dynamometer. The dynamometer pad was then fastened around the leg $5 \mathrm{~cm}$ proximally to the medial malleolus, and the subjects performed a series of three submaximal contractions for familiarization. The subjects then performed three series of ten consecutive maximal eccentric isokinetic contractions; the knee was moved by the dynamometer through the ROM from 20 to $90^{\circ}$ of knee flexion at an angular velocity of $30^{\circ} / \mathrm{s}$ (Figure 1). Each series was preceded by three minutes of resting, and there were no pauses between the ten contractions.

\section{Knee extensor and flexor torque}

Forty-eight hours before and after the training, the peak torque of the knees was assessed, during eccentric isokinetic contractions at $30^{\circ} / \mathrm{s}$. The procedure and the equipment giving peak torque data for each contraction were the same as for the training (see above), except that only one session of five contractions was performed. The peak torque was defined as the maximum value achieved during the five contractions. 
To assess knee functional ability and muscle balance, the hamstrings to quadriceps (H/Q) strength was derived as the ratio between the corresponding peak torques ${ }^{19-21}$.

\section{Knee movements}

Knee flexion/extension and valgus/varus movements were recorded bilaterally using biaxial flexible electrogoniometers and acquisition units (M110, DL1001 and Datalink 2.0, Biometrics Ltd. ${ }^{\circledR}$, Gwent, UK). One goniometer was fixed to the shaved lateral face of each knee. The center of the inter-joint line was considered to be the common reference for the leg and thigh. The center of the sensor springs was mounted so as to coincide with this line, and the two terminals were attached on the sagittal plane of the knee and aligned with the axis of the thigh (with the additional reference point of the greater trochanter of the femur) and the axis of the lower leg (with the external malleolus as the second reference point). The sampling rate was $100 \mathrm{~Hz}$. The reference position (id est $0^{\circ}$ of flexion/extension and valgus/varus) was derived as the mean value over a 16 seconds period, with the subject standing erect and relaxed. Positive angles denoted flexion and valgus. After familiarization with walking on a treadmill at 5km/h, knee movements were recorded for 90 seconds.

\section{Data analysis}

\section{Knee torque and eccentric training}

The knee torque and movements and the effects of training (id est the post-training minus the pre-training value) were calculated for both the left and right knees and evaluated by paired t-tests. The comparison between the right and left sides, both in the stride-based analysis and in the previous method used by Coury et al. ${ }^{17}$, also used paired t-Student test. The data were also tested with regard to the normality of the distribution (Shapiro-Wilk) and homogeneity of variance (Levene). All significance tests were performed at a predetermined alpha level of 0.05. Although no power calculation was made, the sample size was based on studies published in the literature (see Coury et al. ${ }^{17}$, Manal et al..$^{22}$, Kurz et al. ${ }^{23}$, Lavcanska, Taylor e Schache $^{24}$ ).

\section{Knee movements}

From the central part of the electrogoniometric recording, 50 consecutive strides were identified, independently for the right and left sides. From the flexion angles, the heel strikes were detected, defined as the first minimum occurring after the maximum flexion ${ }^{25}$. The heel strike defined the beginning of the strides and, for each stride, the data were normalized to the duration of the stride. During normal gait, as seen in the present study, the first $60 \%$ of the stride represents the stance

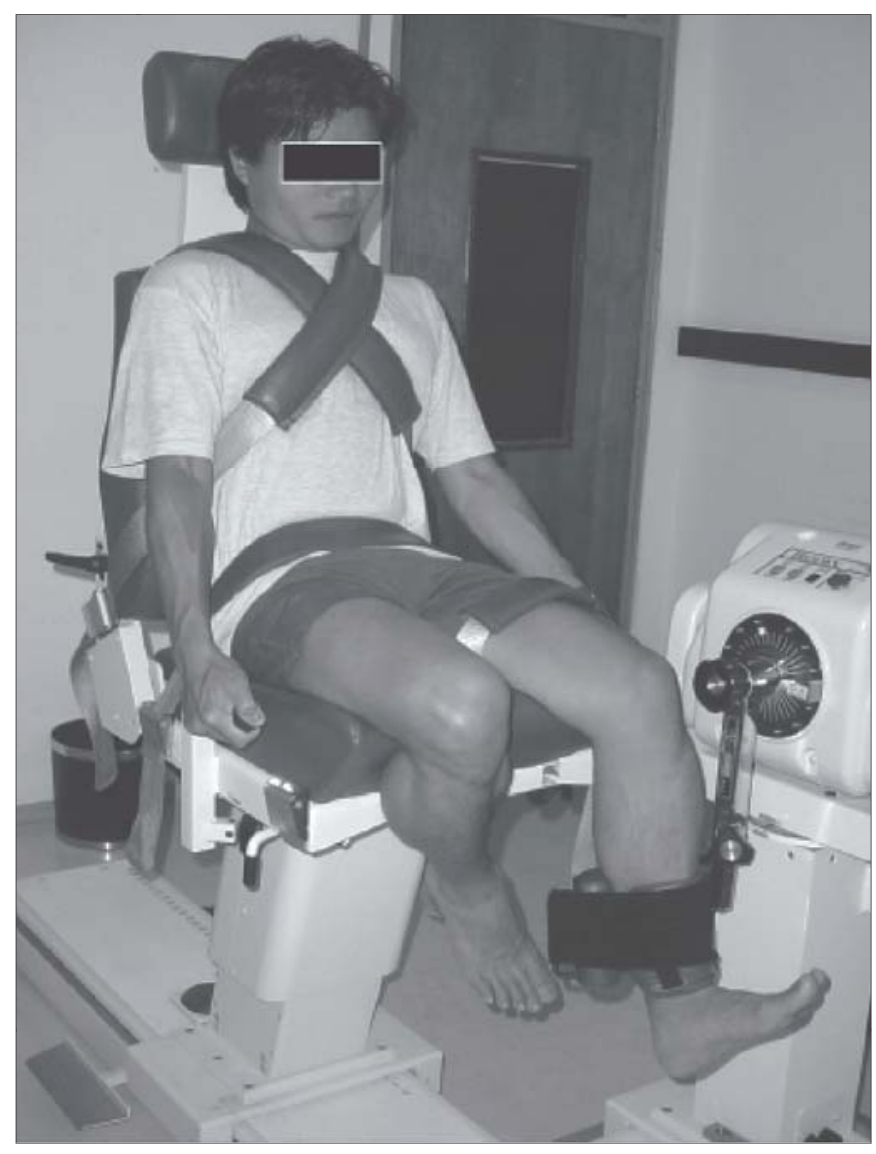

Figure 1. Positioning of the subject in the isokinetic dynamometer during eccentric training of the knee extensor (note the isometric contraction of the flexor in the contralateral limb).

phase and the subsequent $40 \%$, the swing phase ${ }^{25}$. For each stride, the maximum and minimum angles and the ROM (id est the maximum minus the minimum angle) were derived for flexion/extension and valgus/varus. The mean values of theses measurements for the 50 strides were used to characterize the knee movements for each subject. In addition, for each subject and knee, graphs of the mean values for the 50 strides were derived. This analysis was performed using software developed from MatLab 6.5 (MathWorks Inc. ${ }^{\circledR}$, Natick, MA, USA).

\section{Comparative analysis of the electrogoniometric method}

A comparative analysis was made between the present method and the previous method ${ }^{17}$ of electrogoniometric records. For this, the 1 st and $99^{\text {th }}$ percentiles, and the $99^{\text {th }}$ minus the $1^{\text {st }}$ percentile of the angle distributions, were calculated for 60s of the central part of the gait (the same method as used in our previous study ${ }^{17}$ ), for $81 \%$ of the recordings (29 out of 36). The reference position was derived in the same way, and for the same time period, for both methods. We then compared this percentile analysis with the new method used in the present study. 


\section{Results : : .}

\section{Peak torque}

After the isokinetic eccentric training, both the right and the left limb presented increased knee extensor peak torque (38 and $41 \%$ greater, respectively). The right limb increased from $229 \pm 53$ to $304 \pm 53 \mathrm{Nm}(\mathrm{p}<0.01)$ and the left limb increased from $228 \pm 59$ to $311 \pm 63 \mathrm{Nm}$ ( $\mathrm{p}<0.01)$. Although, unexpectedly, the training increased the knee flexor peak torque by $8 \%$ (from $114 \pm 30$ to $123 \pm 22 \mathrm{Nm}, \mathrm{p}<0.05$ ), there was a natural decline in the H/Q ratio of $22 \%$ ( from $0.5 \pm 0.08$ to $0.39 \pm 0.07$, $\mathrm{p}<0.01$ ).

\section{Kinematic analysis}

Means and standard deviations for the maximum, minimum and ROM angles are shown in Table 1, for before and after the training. Regarding the minimum flexion/extension values, there was no noticeable hyperextension during walking, while the average maximum flexion/extension during the swing phase was between 53 and $54^{\circ}$, independent of knee and training. Figure 2, which presents the mean ensemble curves with their standard deviations, for the 18 subjects, shows that the symmetry between the knees and the lack of any effect from the training on the flexion/extension angles applied to all parts of the gait cycle.

There was no significant difference (right knee: $p=0.2$; left knee: $p=0.54$ ) in valgus/varus ROM between pre and post-training measurements, for both knees (Table 1). The maximum and minimum values, as presented in Figure 2, show that the valgus/varus angles, except for the left knee after training, were fairly symmetrically distributed around the reference position. After the training, the left knee displayed a general shift towards valgus, which was most pronounced during the swing phase (the average difference between the mean ensemble curves was $4.1^{\circ}$ ). The increased valgus is also shown by the increased minimum and maximum angles.

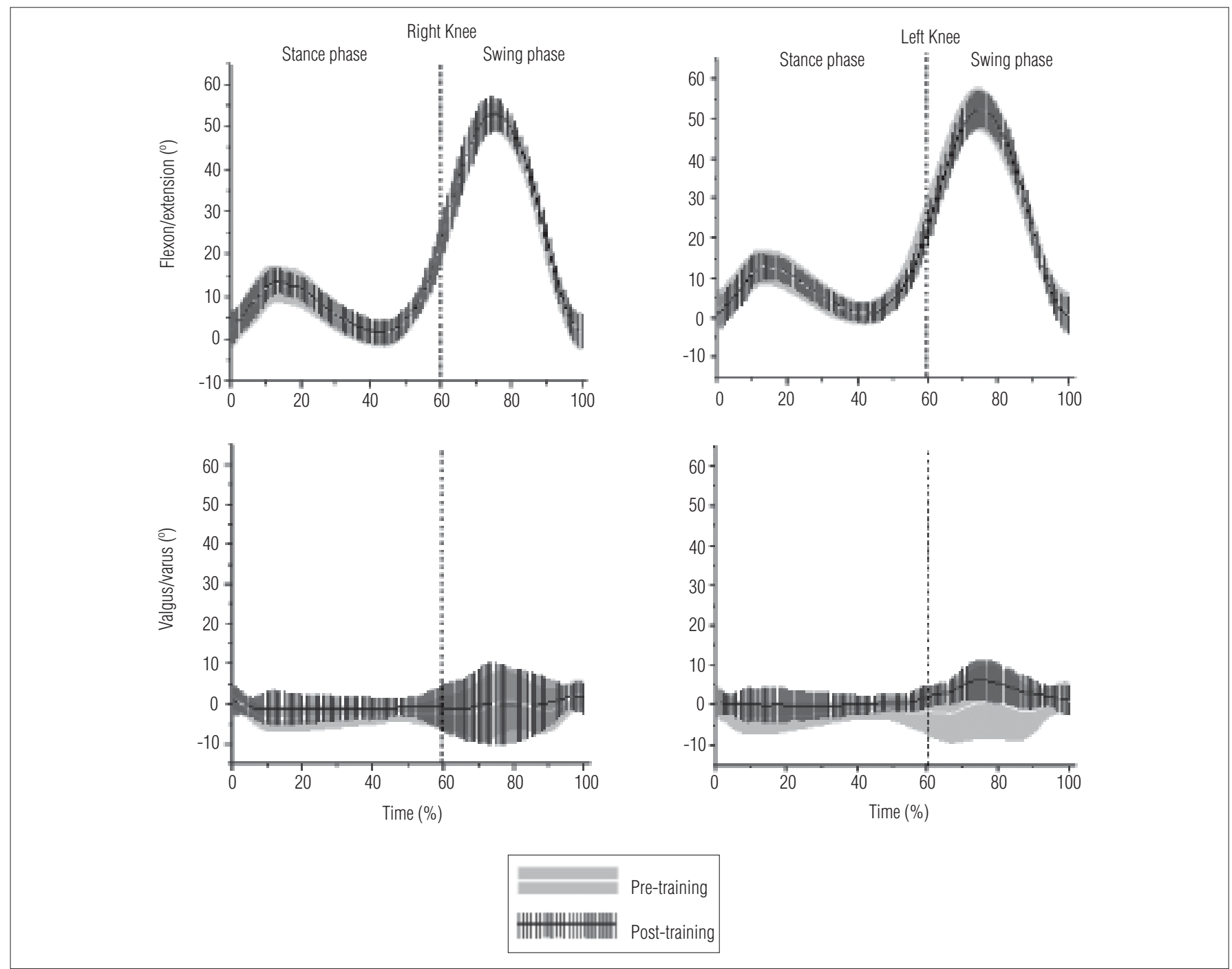

Figure 2. Mean amplitudes and standard deviations of flexion/extension and valgus/varus movements during 100\% of consecutive strides, depicted in the stance and swing phases of gait for both knees before and after training, among 18 healthy male subjects. Positive angles denote flexion and valgus. 
The standard deviations for the maximum and minimum valgus/varus angles were relatively large, compared with the standard deviations for the flexion/extension angles, thus indicating a higher inter-individual variation for valgus/varus than for flexion/extension (Table 1). The standard deviations in Figure 2 also show this relatively large inter-individual variation, and that it was most pronounced during the swing phase. It is interesting to observe that, for valgus/varus, the standard deviation decreased, id est the movement pattern of the subjects became more uniform during the swing phase for the left knee after training.

The kinematic analysis used in our previous study ${ }^{17}$ identified values that were almost identical to those from the present method. The differences in the results from the two methods (previous method minus present method) were: peak flexion $0.5^{\circ}\left(\mathrm{IC} 95 \%=0.4^{\circ}-0.6^{\circ}\right)$, peak extension $0^{\circ}\left(-0.5^{\circ}-0.4^{\circ}\right)$, range of flexion/extension $0.5^{\circ}\left(0.1^{\circ}-1^{\circ}\right)$, peak valgus $-0.5^{\circ}\left(-0.7^{\circ}--0.4^{\circ}\right)$, peak varus $-0.5^{\circ}\left(-0.8^{\circ}--0.3^{\circ}\right)$ and valgus/varus range $0^{\circ}\left(-0.3^{\circ}-0.3^{\circ}\right)$.

\section{Discussion : : :}

The eccentric training increased both the peak extensor torque (by $40 \%$ ) and the peak flexor torque (by $8 \%$ ), but it decreased the H/Q ratio (from 0.5 to 0.39 ). These changes had no significant effect on the gait kinematics of the knee, especially for the valgus/varus ROM, except for a small shift towards valgus for the left knee after the training.

\section{Methodological considerations}

The training in the present study was similar to the training in our previous study ${ }^{17}$, except for shorter duration (six versus 12 weeks in the previous study). In spite of this, the torque gain was higher in the present study (39 versus $25 \%$ in the previous study). The lower efficiency in extensor torque gain during the training in the previous study ${ }^{17}$ was probably because the quadriceps muscle had an abnormal pattern of motor unit recruitment after ACL reconstruction ${ }^{13}$.

One limitation of the present study was that the flexor peak torque was only measured for the nondominant limb, which was done for technical reasons. However, future studies that evaluate both the dominant and the nondominant limb are necessary, since a difference in valgus/varus during gait was found only on the left side.

The use of a stride-based analysis is more relevant for gait evaluation than the more general analysis of amplitude distributions that we have previously used. For technical reasons, only the 29 gait recordings that were recorded using the DL1001 data logger were used for comparing the methods. For
Table 1. Means and mean differences of the flexion/extension and valgus/varus angles of the right and left knees before and after training, among 18 healthy male subjects during gait.

\begin{tabular}{|c|c|c|c|}
\hline \multirow{2}{*}{ Movement } & \multicolumn{3}{|c|}{ Angle $\left({ }^{\circ}\right)$} \\
\hline & Maximum & Minimum & ROM \\
\hline \multicolumn{4}{|c|}{ Flexion/extension } \\
\hline \multicolumn{4}{|c|}{ Right side } \\
\hline Before training & $52.6 \pm 3.7$ & $-0.9 \pm 3.4$ & $53.8 \pm 4.8$ \\
\hline After training & $53.5 \pm 4.2$ & $0 \pm 2.7$ & $53.4 \pm 4.4$ \\
\hline Difference & $0.9 \pm 3.3$ & $0.9 \pm 3$ & $-0.4 \pm 4.7$ \\
\hline$p$-value & 0.27 & 0.22 & 0.72 \\
\hline \multicolumn{4}{|l|}{ Left side } \\
\hline Before training & $53 \pm 5.8$ & $-0.7 \pm 2.8$ & $53.6 \pm 5.9$ \\
\hline After training & $52.5 \pm 4.7$ & $-1.4 \pm 2.6$ & $53.9 \pm 5.4$ \\
\hline Difference & $-0.5 \pm 3.3$ & $-0.7 \pm 2.3$ & $0.2 \pm 3.2$ \\
\hline $\mathrm{p}$-value & 0.55 & 0.23 & 0.79 \\
\hline \multicolumn{4}{|l|}{ Valgus/varus } \\
\hline \multicolumn{4}{|l|}{ Right side } \\
\hline Before training & $5.5 \pm 3.9$ & $-6 \pm 5.3$ & $11.6 \pm 5.2$ \\
\hline After training & $6.4 \pm 6.2$ & $-6.5 \pm 5$ & $12.9 \pm 5.5$ \\
\hline Difference & $0.9 \pm 8.9$ & $-0.5 \pm 7.9$ & $1.4 \pm 4.3$ \\
\hline$p$-value & 0.68 & 0.8 & 0.2 \\
\hline \multicolumn{4}{|l|}{ Left side } \\
\hline Before training & $5.9 \pm 4.9$ & $-6.3 \pm 5.3$ & $12.2 \pm 3.6$ \\
\hline After training & $8.3 \pm 4.1$ & $-3.1 \pm 2.1$ & $11.4 \pm 3.4$ \\
\hline Difference & $2.3 \pm 5$ & $3.2 \pm 5.3$ & $-0.8 \pm 5.5$ \\
\hline$p$-value & 0.06 & 0.02 & 0.54 \\
\hline
\end{tabular}

Note: Results are means \pm standard deviations; positive angles denote flexion and valgus; range of motion=ROM.

the derived measurement, the differences between the two methods were surprisingly small, for both flexion/extension and valgus/varus. The very small and physiologically non-significant differences enabled direct comparisons of the results obtained using the two methods. Moreover, when these methods are used for quantifying the effect of training, as in both the present study and our previous one, differences between pairs of measurements made using the same method are calculated, thus virtually eliminating even the minute differences between the methods. Hence, methodological considerations can be disregarded when comparing the results from the present study and our previous study.

\section{Physiological effects}

As expected, the eccentric training increased the extensor torque of the knees, similarly to what was found in the previous study using a similar training protocol for subjects who had undergone ACL reconstruction ${ }^{17}$. However, the unexpected gain in flexor torque was probably due to isometric contraction in the contralateral limb, performed by the subjects during eccentric actions of the extensors (Figure 1), since muscle strengthening of this group was not in the training program used. Among other factors, the increased flexor 
torque may be due to the hemispheric dominance of the task itself $^{26}$, the size and uniformity of the sample, $\operatorname{sex}^{27}$, age $\mathrm{e}^{28}$, functional asymmetry ${ }^{29}$, motor experience and type of strategies developed during practice ${ }^{26}$.

Nevertheless, the decline in $\mathrm{H} / \mathrm{Q}$ ratio, after the training, indicates that the flexors presented reduced capacity for knee stabilization. This could be considered to be an increased risk of injury. Normal values for H/Q ratio of 0.4 to 0.5 have been reported based on peak moments, independent of contraction mode and velocity ${ }^{19,30}$. The approximate values for $H / Q$ ratio ( $\cong 0.3$ ) suggest that the flexors muscles have a reduced capacity for dynamic knee joint stabilization during forceful knee flexion movements with simultaneous eccentric quadriceps muscle contraction $^{31,32}$. This may reflect predisposition to injury ${ }^{33}$.

The quadriceps muscle contraction may create significant anterior tibial translation or shear, especially at high contraction forces with the knee towards full extension ${ }^{34-36}$, and this may produce substantial internal rotation of the tibia relative to the femur ${ }^{34,37}$. The co-activation of the hamstring muscles, in addition to the ACL tension, will significantly contribute towards counterbalancing the tibial shear ${ }^{32,37}$ or rotation ${ }^{30}$. Therefore, the H/Q ratio may be used to indicate the extent to which the hamstring muscles are capable of counteracting the anterior tibial shear induced by maximal quadriceps muscle contraction ${ }^{19}$. The results from the present study show that when eccentric training is applied exclusively to the quadriceps muscles, it alters the forces involved in knee joint stabilization.

The decline in the H/Q ratio found in this study was a consequence of the higher torque gain of the knee extensor (about 40\%), compared with the torque gain of the knee flexor (8\%). However, this result seems to only marginally affect the gait pattern in normal subjects. Specifically, no increase in valgus/varus ROM was observed, while such an increase was the main finding in our previous study on ACL reconstruction patients. Such patients are probably more susceptible to alterations in gait kinematics due to eccentric training, and also present higher values in the $\mathrm{H} / \mathrm{Q}$ ratio. If the decline in $\mathrm{H} / \mathrm{Q}$ ratio is the same as in the present study, the mechanical properties of the ligaments may be more sensitive to increased extensor torque, even when partly balanced by antagonistic torque of the flexors. Thus, to prevent ACL reconstruction patients from developing degenerative complications, secondary to the primary injury, rehabilitation that restores functional knee kinematics during gait seems important. Since eccentric exercise is an effective method for strengthening the knee extensors, complementary eccentric training of the knee flexors may be required, in order to maintain a normal $\mathrm{H} / \mathrm{Q}$ ratio and avoid possible abnormalities in the gait kinematics.

The comparison between the results from this study and our previous report ${ }^{17}$ indicates that some aspects of the effects of eccentric training on knee gait parameters in normal and ACL reconstruction subjects still remain to be considered in future studies. For example, it would be interesting to assess the effect of bilateral eccentric training of knee flexors and extensors on the gait pattern of normal and ACL reconstruction subjects, and also the effects of different combinations of frequency and duration of training.

\section{Conclusions : $:$.}

Isokinetic eccentric training of knee extensors increased the torque of the knee extensor and decreased the H/Q ratio, but the effect on the gait pattern seems negligible in healthy subjects. Associated training of knee flexors, complementary to the training of the extensors, might be necessary in order to maintain the balance between knee agonists and antagonists.

\section{Acknowledgements $: \because$.}

Financial support from the Fundação de Amparo à Pesquisa do Estado de São Paulo, (Fapesp), and the Conselho Nacional de Desenvolvimento Cientifico e Tecnológico (CNPq). Patrícia Rios Poletto and Heleodório Honorato Santos hold PhD bursaries from the Coordination Office for the Coordenação de Aperfeiçoamento de Pessoal de Nível Superior (Capes).

\section{Referências bibliográficas $: \because$.}

1. Knoll Z, Kiss RM, Kocsis L. Gait adaptation in ACL deficient patients before and after anterior cruciate ligament reconstruction surgery. J Electromyogr Kinesiol. 2004;14(3):287-94.

2. Yoo JD, Papannagari R, Park SE, DeFrate LE, Gill TJ, Li G. The effect of anterior cruciate ligament reconstruction on knee joint kinematics under simulated muscle loads. Am J Sports Med. 2005;33(2):240-6.
3. Shelburne KB, Torry MR, Pandy MG. Effect of muscle compensation on knee instability during ACL-deficient gait. Med Sci Sports Exerc. 2005;37(4):642-8.

4. Bulgheroni P, Bulgheroni MV, Andrini L, Guffanti P, Giughello A. Gait patterns after anterior cruciate ligament reconstruction. Knee Surg Sports Traumatol Arthr. 1997;5(1):14-21. 
5. Kvist J, Gillquist J. Anterior positioning of tibia during motion after anterior cruciate ligament injury. Med Sci Sports Exerc. 2001;33(7):1063-72.

6. Ernst GP, Saliba E, Diduch DR, Hurwitz SR, Ball DW. Lower extremity compensations following anterior cruciate ligament reconstruction. Phys Ther. 2000;80(3):251-60.

7. Williams GN, Snyder-Mackler L, Barrance PJ, Buchanan TS. Quadriceps femoris muscle morphology and function after ACL injury: a differential response in coopers versus non-coopers. J Biomech. 2005;38(4):685-93.

8. McHughMP,TylerTF,BrowneMG,GleimGW,NicholasSJ.Electromyographic predictors of residual quadriceps muscle weakness after anterior cruciate ligament reconstruction. Am J Sports Med. 2002;30(3):334-9.

9. Konishi Y, Fukubayashi T, Takeshita D. Possible mechanism of quadriceps femoris weakness in patients with ruptured anterior cruciate ligament. Med Sci Sports Exerc. 2002:34(9):1414-8.

10. Wilk KE, Romaniello WT, Soscia SM, Arrigo CA, Andrews JR. The relationship between subjective knee scores, isokinetic testing in the ACLreconstructed knee. J Orthop Sports Phys Ther. 1994;20(2):60-73.

11. LaStayo PC, Woolf JM, Lewek MD, Snyder-Mackler L, Reich T, Lindstedt SL. Eccentric muscle contractions: their contribution to injury, prevention, rehabilitation, and sport. J Orthop Sports Phys Ther. 2003;33(10):557-71.

12. Miller LE, Pierson LM, Nickols-Richardson SM, Wootten DF, Selmon SE, Ramp WK et al. Knee extensor and flexor torque development with concentric and eccentric isokinetic training. Res Q Exec Sport. 2006;77(1):58-63.

13. Goldspink G. Molecular mechanisms involved in the determination of muscle fibre mass and phenotype. Adv Exerc Sports Physiol. 1999;5(2):27-39.

14. Gibala MJ, Interisano SA, Tarnopolsky MA, Roy BD, MacDonald JR, Yarasheski KE et al. Myofibrillar disruption following acute concentric and eccentric resistance exercise in strength-trained men. Can J Physiol Pharmacol. 2000;78(8):656-61.

15. McDonagh MJ, Davies CT. Adaptive response of mammalian skeletal muscle to exercise with high loads. Eur J Appl Physiol Occup Physiol. 1984;52(2):139-55.

16. Seger JY, Thorstensson A. Effects of eccentric versus concentric training on thigh muscle strength and EMG. Int J Sports Med. 2005;26(1):45-52.

17. Coury HJ, Brasileiro JS, Salvini TF, Poletto PR, Carnaz L, Hansson GA. Change in knee kinematics during gait after eccentric isokinetic training for quadriceps in subjects submitted to anterior cruciate ligament reconstruction. Gait Posture. 2006;24(3):370-4.

18. Brasileiro JS. Alterações funcionais e morfológicas do músculo quadríceps induzidas pelo treinamento excêntrico após reconstrução de LCA. (tese de Doutorado), São Carlos (SP): UFSCar; 2004.

19. Aagaard P, Simonsen EB, Trolle M, Bangsbo J, Klausen K. Isokinetic hamstring/quadriceps strength ratio: influence from joint angular velocity, gravity correction and contraction mode. Acta Physiol Scand. 1995;154(4):421-7.

20. Li RC, Maffulli N, Hsu YC, Chan KM. Isokinetic strength of the quadriceps and hamstrings and functional ability of anterior cruciate deficient knees in recreational athletes. Br J Sports Med. 1996;30(2):161-4.
21. Rosene JM, Forgarty TD, Mahaffey BL. Isokinetic Hamstrings: Quadriceps Ratios in Intercollegiate Athletes. J Athl Train. 2001;36(4):378-83.

22. Manal K, McClay Davis I, Galinat B, Stanhope S. The accuracy of estimating proximal tibial translation during natural cadence walking: bone vs. skin mounted targets. Clin Biomech (Bristol, Avon). 2003;18(2):26-31.

23. Kurz MJ, Stergiou N, Buzzi UH, Georgoulis AD. The effect of anterior cruciate ligament recontruction on lower extremity relative phase dynamics during walking and running. Knee Surg Sports Traumatol Arthrosc. 2005;13(2):107-15.

24. Lavcanska V, Taylor NF, Schache AG. Familiarization to treadmill running in young unimpaired adults. Human Mov Sci. 2005;24(4):544-57.

25. Kettelkamp DB, Johnson RJ, Smidt GL, Chao EY, Walker M. An electrogoniometric study of knee motion in normal gait. J Bone Joint Surg Am. 1970;52(4):775-90.

26. Schulze K, Lülders E, Jäncke L. Intermanual transfer in a simple motor task. Cortex. 2002;38(5):805-15.

27. Schmidt SL, Oliveira RM, Rocha FR, Abreu-Villaça Y. Influences of handedness and gender on the grooved pegboard test. Brain Cogn. 2000;44(3):445-54.

28. Uehara I. No transfer of visuomotor learning of button-pressing from right to left hands in right-handed four-year-olds. Percept Mot Skills. 1998;87(3 Pt 2):1427-40.

29. Stoddard L, Vaid J. Asymmetries in intermanual transfer of maze learning in right-and left-handed adults. Neuropsychologia. 1996;34(6):605-8.

30. Westing SH, Seger JY. Eccentric and concentric torque-velocity characteristics, torque output comparisons, and gravity effect torque corrections for the quadriceps and hamstring muscles in females. Int $\mathrm{J}$ Sports Med. 1989;10(3):175-80.

31. Aagaard P, Simonsen EB, Trolle M, Bangsbo J, Klausen K. Specificity of training velocity and training load on gains in isokinetic knee joint strength. Acta Physiol Scand. 1996;156(2):123-9.

32. Dvir Z. Isokinetics: Muscle testing, interpretation and clinical applications. $2^{\text {nd }}$ ed. Edinburgh: Churchill Livingstone; 2004.

33. Baratta R, Solomonow M, Zhou BH, Letson D, Chuinard R, D'Ambrosia R. Muscular coactivation. The role of the antagonist musculature in maintaining knee stability. Am J Sports Med. 1988;16(2):113-22.

34. Hirokawa S, Solomonow M, Lu Y, Lou ZP, D’Ambrosia R. Anterior-posterior and rotational displacement of the tibia elicited by quadriceps contraction. Am J Sports Med. 1992;20(3):299-306.

35. Kaufman KR, An KN, Litchy WJ, Morrey BF, Chao EY. Dynamic joint forces during knee isokinetic exercise. Am J Sports Med. 1991;19(3):305-16.

36. Nisell R, Ericson M0, Németh G, Ekholom J. Tibiofemoral joint forces during isokinetic knee extension. Am J Sports Med. 1989;17(1):49-54.

37. More RC, Karras BT, Neiman R, Fritschy D, Woo SL, Daniel DM. Hamstringsan anterior cruciate ligament protagonist. An in vitro study. Am J Sports Med. 1993;21(2):231-7. 